
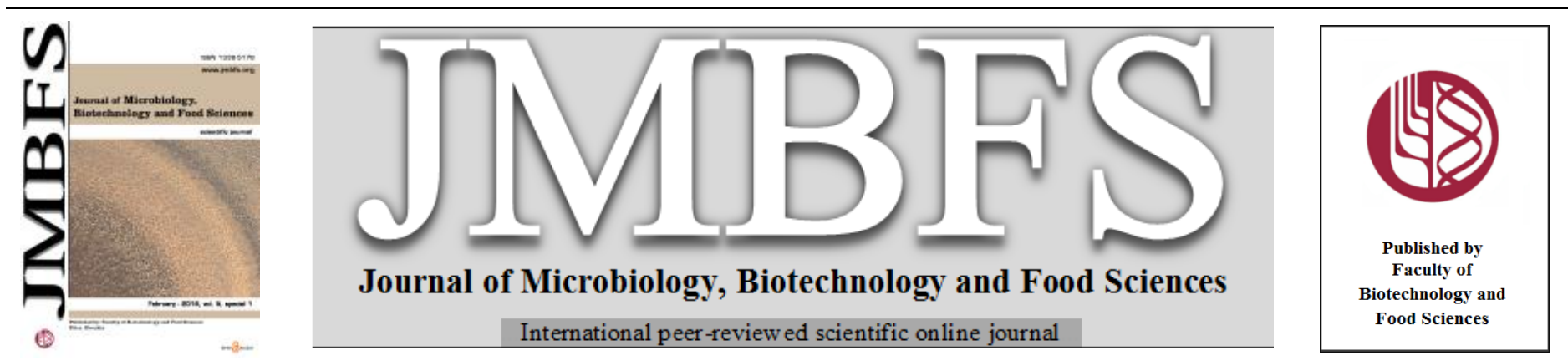

\title{
DO PROGESTERONE, IGF-I, IGFBP-3 AND IGFBP-4 RELATE TO SEXUAL MATURATION?
}

\author{
Adriana Kolesárovál, Alexander V. Sirotkin ${ }^{2}$, Shubhadeep Roychoudhury ${ }^{3}$, Jaroslav Kováčik $^{1}$
}

\author{
Address(es): \\ ${ }^{1}$ Department of Animal Physiology, Faculty of Biotechnology and Food Sciences, Slovak University of Agriculture in Nitra, Tr. A. Hlinku 2, 94976 Nitra, Slovak \\ Republic. \\ ${ }^{2}$ Animal Production Research Centre Nitra, National Agricultural and Food Center, Lužianky, Slovak Republic. \\ ${ }_{3}^{3}$ Department of Life Science and Bioinformatics, Hargobind Khurana School of Life Sciences, Assam University, Silchar, India.
}

*Corresponding author: Adriana.Kolesarova@uniag.sk

doi: 10.15414/jmbfs.2016.5.special1.40-43

\section{ARTICLE INFO}

Received 24. 12. 2015

Revised 28. 1. 2016

Accepted 30.1.2016

Published 8. 2. 2016

Regular article

OPEN $\partial_{\text {ACCESS }}$

\section{ABSTRACT}

Hormones and binding proteins can regulate reproduction, but their involvement in sexual maturation remains to be elucidated. This study describes possible hormonal regulators of female sexual maturation. For this purpose, the release of steroid hormone progesterone $\left(\mathrm{P}_{4}\right)$, insulin-like growth factor I (IGF-I) and IGF-binding proteins (IGFBP-3, IGFBP-4) were shown in this study. Sexual maturation in gilts was found to be associated with a significant increase in the release of $\mathrm{P}_{4}$, IGF-I and IGFBP-3 in vitro. Furthermore, sexual maturation was associated with significant increase in the expression of IGFBP-3 but not in IGFBP-4. The present data obtained from in vitro study indicate that sexual maturation in females is influenced by puberty-related changes in porcine ovarian signalling substances: increase in $\mathrm{P}_{4}$, IGF-I, IGFBP-3 but not IGFBP-4. It suggests that these signalling molecules could be potential regulators of porcine sexual maturation.

Keywords: Sexual maturation, porcine granulosa cells, progesterone, insulin-like growth factor I and IGF-binding proteins

\section{INTRODUCTION}

Sexual maturation is associated with ovarian follicular growth and differentiation (Onagbesan et al., 2009; Palma et al., 2012). These processes are governed by hormones, growth factors and their binding proteins (Kolesarova et al., 2008; Sirotkin, 2013). There is indirect evidence for involvement of several candidate signalling substances in control of sexual maturation and/or related ovarian follicle development. Steroid hormone progesterone $\left(\mathrm{P}_{4}\right)$ is essential for normal ovarian cycles (Arnhold et al., 2009; Hagan et al., 2009) and contributes to regulation of ovarian follicular development and remodelling (Astiz, 2013; Mahajan, 2008). Progesterone produced by porcine ovarian granulosa cells (Duda et al., 2012; Kolesarova et al., 2009b, 2010) and the corpus luteum (Gregoraszczuk, 1992,1997; Mahajan, 2008; Shah and Nagarajan, 2013) is a local paracrine or autocrine promoter of ovarian cell luteinization (Gregoraszczuk, 1994). In cyclic animals, when the early follicular growth is initiated, a high amount of $\mathrm{P}_{4}$ is secreted by secondary, tertiary and luteinized ovarian follicles and active corpora lutea, into the peripheral blood (Mahajan, 2008).

Insulin-like growth factor I (IGF-I) is known to stimulate ovarian follicular growth (Lucy, 2008) and development (Carter et al., 2006) by promoting granulosa cell proliferation, follicular antrum formation (Mao et al., 2004), hyperplasia of ovarian surface epithelium (King et al., 2013), releasing ovarian hormones (Kolesarova et al., 2008) and decreasing ovarian cell apoptosis (Mao et al., 2004). IGF-I has been found to be produced by porcine (Kolesarova $\boldsymbol{e t}$ al., 2008, 2009b, 2010), chicken (Sirotkin et al., 2006) and human (Karamouti et al., 2008) ovarian cells. The effects of IGF-I on the ovary may be modified by the local production of IGF binding proteins (IGFBPs) (Sandhu et al., 2002; Yi $\boldsymbol{e}$ al., 2001). In the ovary, IGFBP-3 appears to neutralize the actions of IGF-I (Bicsak et al., 1990,1991; Ui et al., 1989). IGFBP-3 not bound to IGF also affects cells via mechanisms involving binding to specific cell surface receptors and/or transport into the cell (Xi et al., 2007). IGFBP-4 modulates autocrine/paracrine action of IGF in both follicular growth and differentiation in the porcine ovary (Zhou et al., 1996). The secretion of IGFBP-4 is higher in immature granulosa cells as compared to mature porcine ovarian follicles (Grimes et al., 1994).

The general aim of the in-vitro experiments with porcine ovarian granulosa cells was to identify possible hormonal regulators of female sexual maturation. For this purpose, these signaling molecules were evaluated in granulosa cells collected from sexually mature and immature gilts.

\section{MATERIALS AND METHODS}

Animals

Healthy gilts of Slovakian White breed were reared under standard conditions at the Experimental Station of the Slovak University of Agriculture in Nitra, Slovakia. Conditions of their care and handling corresponded to the instructions of the European Commission (EC) no. 178/2002 and related EC documents and as approved by local ethics committee. Animals $(\mathrm{n}=35)$ were assigned at slaughter into two groups: sexually immature $(n=18)$ and animals of the same age having reached sexual maturity $(\mathrm{n}=17)$ according to visual characteristics of ovaries (presence of follicles larger than $5 \mathrm{~mm}$ ).

\section{Preparation, culture and processing of granulosa cells}

Ovaries were transported to the laboratory at $4^{\circ} \mathrm{C}$ and washed in sterile physiological solution. Ovaries from immature and mature gilts were processed separately. Follicular fluid was aspirated from 3-5 mm follicles, granulosa cells were isolated by centrifugation for $10 \mathrm{~min}$ at $200 \mathrm{xg}$ followed by washing in sterile DMEM/F12 1:1 medium (BioWhittaker ${ }^{\mathrm{TM}}$, Verviers, Belgium) and resuspended in the same medium supplemented with $10 \%$ fetal calf serum (BioWhittaker ${ }^{\mathrm{TM}}$ ) and 1\% antibotic-antimycotic solution (Sigma, St. Louis, Mo, USA) at a final concentration of $10^{6}$ cells $/ \mathrm{mL}$ of medium. Portions of the cell suspension were dispensed to 24-welled culture plates (Nunc ${ }^{\mathrm{TM}}$, Roskilde, Denmark, $1 \mathrm{ml} /$ well; for RIA) or Lab-Tek 16-welled chamber slides (Nunc Inc., International, Naperville, USA, $100 \mu \mathrm{l} / \mathrm{well}$; for immunocytochemistry). Both the plate wells and chamber slides were incubated at $37.5^{\circ} \mathrm{C}$ and $5 \% \mathrm{CO}_{2}$ in humidified air until a $75 \%$ confluent monolayer was formed (5-7 days), at which point the medium was replaced with fresh medium. Further culture was performed in $300 \mu 1$ medium in 16-welled chamber slide cells or $1 \mathrm{ml}$ of culture plate. After 2 days of culture the media from wells were removed, wells from chamber slides were washed in ice-cold PBS (ph 7.5). Cells were fixed for $1 \mathrm{~h}$ at room temperature in $4 \%$ paraformaldehyde, dehydrated in alcohols $(70,80,96 \%$; $10 \mathrm{~min}$ each) and stored in $96 \%$ alcohol at $-4^{\circ} \mathrm{C}$ to await immunocytochemical analysis. Media from plate wells were aspirated and kept at $-70{ }^{\circ} \mathrm{C}$ to await RIA. 
Immunocytochemistry was used to detect IGFBP-3, IGFBP-4 in granulosa cells plated on chamber slides. Primary mouse monoclonal antibodies to each petide IGFBP-3, IGFBP-4 (cross-reacting with corresponding rat, human, porcine and chicken substances; all from Santa Cruz Biotechnology Inc., Santa Cruz, CA USA) were used as directed by the manufacturer at a dilution of 1:100 Visualisation of the primary antibody binding sites was done with a secondary rabbit polyclonal antibody against mouse IGs, labelled with horseradish peroxidase (Sevac, Prague, Czech Republic; dilution 1:500) and diaminobenzidine (DAB) reagent (Roche Diagnostics Corporation, IN, USA $10 \%$ ). The presence of each peptide was determined by light microscopy. To verify these data, in some selected cases primary antibodies were visualised by secondary rabbit or goat monoclonal antibodies against mouse IGs labelled with FITC (Sevac, Prague, Czech Republic) and fluorescent microscopy. Negative control was presented by stained cells omitting primary antibody. During microscopic inspection, the percentage of cells containing visible antigen was determined.

\section{Immunoassay}

Levels of progesterone and IGFBP-3 were determined in duplicate in 20-100 $\mu$ samples by radioimmunoassay (RIA). Progesterone and IGFBP-3 were evaluated after ethanol extraction using RIA kits from DSL (Webster, USA) according to manufacturer's instructions while IGF-I was assayed as described previously. All RIA were validated for use in samples of culture medium. RIA assay for $\mathrm{P}_{4}$ : the antiserum cross-reacted was $<0.001 \%$, the sensitivity was $0.12 \mathrm{ng} / \mathrm{mL}$. RIA assay for IGFBP-3: the antiserum cross-reacted was $<0.03 \%$, the sensitivity was 0.5 $\mathrm{ng} / \mathrm{mL}$. RIA assay for IGF-I: Inter- and intra-assay coefficients of variation did not exceed $10 \%$ and $16 \%$, respectively. The sensitivity of the assay as determined by the dilution method was $0.3 \mathrm{ng} / \mathrm{mL}$.

\section{Statistics}

Each experimental group was represented by four culture wells with granulosa cells. Assays of hormonal substances in incubation medium were performed in duplicate. The data presented concerning the effects of each substance are means of values obtained in three separate experiments performed on separate days using separate ovaries. The values of blank controls were subtracted from the values determined by RIA in cell-conditioned medium to exclude any nonspecific background (less than 13\% of total values). The rates of hormone secretion were calculated per $10^{6}$ cells per day. The proportion of cells containing each analysed substance was calculated following immunocytochemical analysis by counting at least 1000 cells per chamber slide well. Firstly, the data obtained in each experiment were processed by ANOVA. Thereafter, significant differences between the immature groups and mature gilts were evaluated by paired t-test or chi-square $\left(\chi^{2}\right)$ test by using statistical software Sigma Plot 9.0 (Jandel, Corte Madera, USA). Differences from controls $(\mathrm{P}<0.05)$ were considered as significant.

\section{RESULTS}

Release of progesterone by ovarian granulosa cells was significantly higher $(\mathrm{p}<0.05)$ in sexually mature gilts $(5.3 \pm 0.1 \mathrm{ng} / \mathrm{mL}$ vs $4.3 \pm 0.3 \mathrm{ng} / \mathrm{mL})$ in comparison to sexually immature animals (Fig. 1). Release of IGF-I also followed the same pattern $(7.8 \pm 0.6 \mathrm{ng} / \mathrm{mL}$ vs $6.2 \pm 0.2 \mathrm{ng} / \mathrm{mL}$ ) (Fig. 1). Percentage of ovarian granulosa cells expressing IGFBP-3 was also significantly higher $(\mathrm{p}<0.05)$ in sexually mature gilts $(53.1 \pm 0.4 \%)$ than the immature animals $(36.5 \pm 2.3 \%)$ (Fig. 2). Although the IGFBP-4 expression by granulosa cells did not change significantly with sexual maturity $(41.9 \pm 02.3 \%$ in mature gilts vs. $37.2 \pm 3.1 \%$ in immature ones) (Fig. 2).

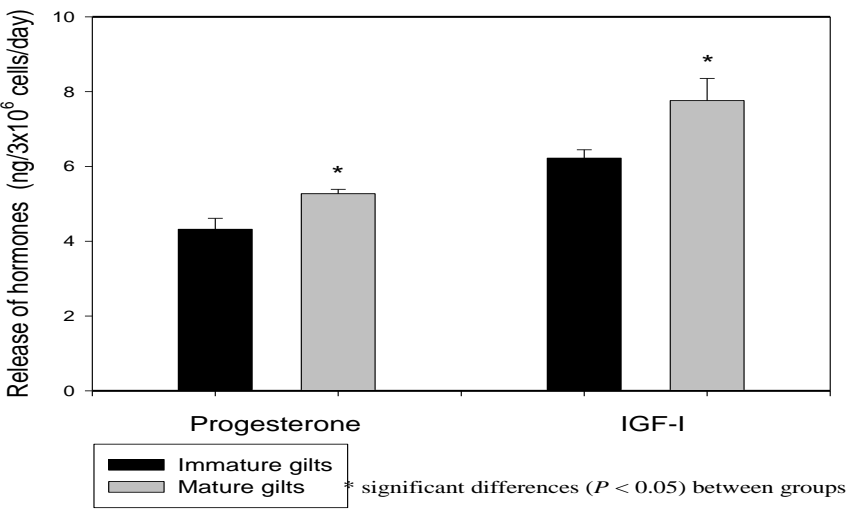

Figure 1 Release of progesterone and IGF-I by ovarian granulosa cells of sexually immature and mature gilts. Values are means $\pm \mathrm{SD}$, *significant difference $(P<0.05)$ between corresponding groups of sexually immature $(\mathrm{n}=18)$ and mature $(n=17)$ gilts were evaluated by paired t-test and chi-square $\left(\chi^{2}\right)$ test.

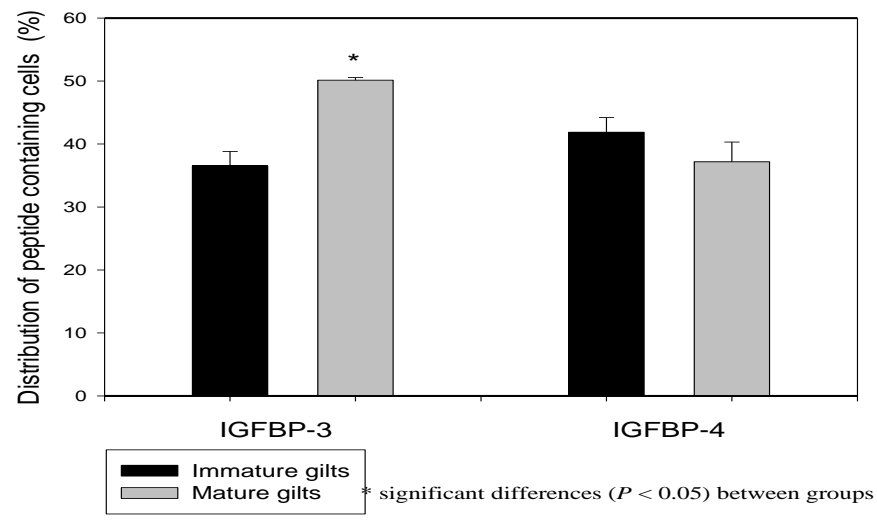

Figure 2 Expression of IGFBP-3 and IGFBP-4 in ovarian granulosa cells of sexually immature and mature gilts. Values are means $\pm \mathrm{SD}$, *significant difference $(P<0.05)$ between corresponding groups of sexually immature $(\mathrm{n}=18)$ and mature $(\mathrm{n}=17)$ gilts were evaluated by paired $\mathrm{t}$-test and chi-square $\left(\chi^{2}\right)$ test.

\section{DISCUSSION}

Do progesterone, IGF-I, IGFBP-3 and IGFBP-4 relate to sexual maturation?

The previous observation in primates, rats, cattle (Prunier and Louveau, 1997) and pig (Kolesarova et al., 2010; Kolesarova et al., 2008) make it clear that sexual maturation was associated with the increase in blood concentrations of IGF-I. In vivo results concerning IGF-I levels in blood plasma in the study of Kolesarova et al. (2008) were also confirmed by in vitro results from IGF-I release by cultured ovarian granulosa cells indicating the sexual maturationdependent increase in gilts. We report that increase in IGF-I release in vitro in gilts was associated with sexual maturation, and that therefore IGF-I may be involved in control of this process.

In our previous study (Kolesarova et al., 2008), we also noted lower $(\mathrm{p}<0.05)$ levels of IGFBP-3 in blood plasma and granulosa cells of sexually immature gilts in comparison to mature animals. These results confirm our previous in vivo study (Kolesarova et al., 2010). Plasma 43-39 kDa IGFBP levels were found to increase whereas plasma $34 \mathrm{kDa}$ IGFBP decreased with age $(\mathrm{p}<0.01)$ (Prunier and Louveau, 1997).

Expression of IGFBP-4 in granulosa cells did not change with sexual maturity (Kolesarova et al., 2008). Grimes et al. (1994) reported that the secretion of IGFBP-4 was higher in granulosa cells from immature porcine ovarian follicles (Grimes et $\boldsymbol{a l}$. , 1994). Low molecular weight IGFBPs, especially IGFBP-4, was the highest in small immature follicles that are predominantly atretic in pigs (Howard et al., 1991; Mondschein et al., 1991; Ryan, 1981). Our observations, together with previous reports (Liu et al., 1993; Sirotkin et al., 2001) suggest that IGFBPs could be important regulators of follicular growth and differentiation. 


\section{Possible interrelationships between studied substances}

Certain changes observed in our investigations could be primary; others could be secondary, i.e. mediated by upstream regulators. For example, changes in $\mathrm{P}$ release may be due to changes in IGF-I output. At least a positive relationship between $\mathrm{P}_{4}$ and IGF-I concentrations in porcine blood (Langendijk $\boldsymbol{e t}$ al., 2008) and the ability of IGF-I to activate porcine ovarian steroid hormone release (Sirotkin et al., 2004) has been reported. The opposite action of steroids on IGFI is less probable because previous study showed that gonad steroids are not involved or play only a minor role in the control of IGF-I and IGFBP plasma levels during pubertal development in gilts (Prunier and Louveau, 1997) Previous authors showed stimulatory action of IGF-I on granulosa cell steroidogenesis which increased with follicular development, whereas its mitogenic action on granulosa cells decreased with follicular phase progression (Kolodziejczyk et al., 2003). Interrelationships between IGF-I and IGFBPs are well known. A strong positive correlation between IGF-I and IGFBP-3 concentration was apparent with increasing age of the animals suggesting functional interrelations between the substances during sexual maturation (Lee $\boldsymbol{e}$ al., 2002). Cooperation between IGF-I and IGFBP-4 in control of porcine ovarian folliculogenesis, follicular selection and luteinization was outlined earlier (Grimes et al., 1994), wherein increased expression of both IGF-I and IGFBP-4 mRNAs during follicular selection and luteinisation was reported. Furthermore, it was observed that the action of IGFBP-4 on the ovary can be mediated by modulation (Zhou et al., 1996) or stimulation (Sirotkin et al., 2001) of IGF-I release and/or by inhibition of $\mathrm{P}_{4}$ output (Sirotkin et al., 2001). Therefore, ovarian follicular growth, selection, luteinization and related increase in progesterone release during porcine sexual maturation can be regulated by members of ovarian IGF-I/IGFBP system. In our experiments, the pubertyrelated changes in IGF-I, IGFBP-3 and $\mathrm{P}_{4}$, but not in IGFBP4 were observed (Kolesarova et al., 2008).

\section{CONCLUSION}

The present data obtained from in vitro study indicate that sexual maturation in females is influenced by puberty-related changes in porcine ovarian signaling substances: increase in $\mathrm{P}_{4}$, IGF-I, IGFBP-3 but not IGFBP-4. It suggests that these signaling molecules could be potential regulators of porcine sexual maturation. Therefore, it may be suggested that porcine sexual maturation can be regulated by IGF-I-IGFBP3-P $\mathrm{P}_{4}$, but not by IGF-I-IGFBP4-P 4 system. Although the puberty-related changes don't provide direct evidence of the involvement and physiological role of these signaling molecules in control of sexual maturation, our study enables to identify extracellular signaling substances, which could be potential candidates for induction of porcine puberty and sexual maturation.

Acknowledgments: This work was financially supported by the Ministry of Education, Science, Research and Sport of the Slovak Republic projects no. 1/0022/13 and APVV-0304-12.

\section{REFERENCES}

Arnhold, I.J., Lofrano-Porto, A., Latronico, A.C. (2009). Inactivating mutations of luteinizing hormone beta-subunit or luteinizing hormone receptor cause oligoamenorrhea and infertility in women. Hormone Research 71, 75-82. http://dx.doi.org/10.1159/000183895

Astiz, S., Gonzalez-Bulnes, A., Perez-Solana, M., Sanchez-Sanchez, R., TorresRovira, L. (2013). In vitro release of ovarian progesterone is decreased during the oestrous cycle and pregnancy of swine with obesity/leptin resistance. Reproduction in Domestic Animals 48, e44-48. http://dx.doi.org/10.1111/rda.12148

Bicsak, T.A., Ling, N., De Paolo, L.V. (1991). Ovarian intrabursal administration of insulin-like growth factor-binding protein inhibits follicle rupture in gonadotropin-treated immature female rats. Biology of Reproduction 44, 599-603. http://dx.doi.org/10.1095/biolreprod44.4.599

Bicsak, T.A., Shimonaka, M., Malkowski, M., Ling, N. (1990). Insulin-like growth factor-binding protein (IGFBP) inhibition of granulosa cell function: effect on cyclic adenosine 3',5'-monophosphate, deoxyribonucleic acid synthesis, and comparison with the effect of an IGF-I antibody. Endocrinology 126, 21842189.

Carter, A.M., Nygard, K., Mazzuca, D.M., Han, V.K. (2006). The expression of insulin-like growth factor and insulin-like growth factor binding protein mRNAs in mouse placenta. Placenta 27, 278-290.

Duda, M., Durlej-Grzesiak, M., Tabarowski, Z., Slomczynska, M. (2012). Effects of testosterone and 2-hydroxyflutamide on progesterone receptor expression in porcine ovarian follicles in vitro. Reproduction Biology 12, 333-340. http://dx.doi.org/10.1016/j.repbio.2012.10.006

Gregoraszczuk, E.L. (1992). Interrelations between steroid hormone secretion and morphological changes of porcine corpora lutea at various periods of luteal phase. Endocrinological Regulation 26, 189-194.
Gregoraszczuk, E.L. (1994). Is progesterone a modulator of luteal steroidogenesis in pig? A tissue culture approach. Folia Histochemistry and Cytobiology 32, 31-33.

Gregoraszczuk, E.L. (1997). Progesterone, androgen and estradiol production by porcine luteal cell subpopulations: dependence on cell composition and periods of luteal phase. Endocrinological Regulation 31, 41-46.

Grimes, R.W., Barber, J.A., Shimasaki, S., Ling, N., Hammond, J.M. (1994) Porcine ovarian granulosa cells secrete insulin-like growth factor-binding proteins -4 and -5 and express their messenger ribonucleic acids: regulation by follicle-stimulating hormone and insulin-like growth factor-I. Biology of Reproduction 50, 695-701

Hagan, C.R., Faivre, E.J., Lange, C.A. (2009). Scaffolding actions of membraneassociated progesterone receptors. Steroids 74, 568-572. http://dx.doi.org/10.1016/j.steroids.2008.12.004

Howard, H.J., Ford, J., Koohmaraie, M. (1991). Associations between insulinlike growth factor binding proteins and hormone changes in follicular fluid of sows after weaning. Journal of Animal Science 70, 260.

King, S.M., Modi, D.A., Eddie, S.L., Burdette, J.E. (2013). Insulin and insulinlike growth factor signaling increases proliferation and hyperplasia of the ovarian surface epithelium and decreases follicular integrity through upregulation of the PI3-kinase pathway. Journal of Ovarian Research 6 , 12. http://dx.doi.org/10.1186/1757-2215-6-12

Karamouti, M., Kollia, P., Kallitsaris, A., Vamvakopoulos, N., Kollios, G., Messinis, I.E. (2008). Growth hormone, insulin-like growth factor I, and leptin interaction in human cultured lutein granulosa cells steroidogenesis. Fertility and Sterility 90, 1444-1450. http://dx.doi.org/10.1016/j.fertnstert.2007.08.076

Kolesárová, A., Sirotkin, A.V., Kováčik, J. Endokrinné a vnútrobunkové mechanizmy pohlavného dospievania prasničiek. 1. vyd. Nitra : Slovenská pol'nohospodárska univerzita v Nitre, 2008. $131 \mathrm{~s}$. ISBN 978-80-552-0109-2.

Kolesarova, A., Sirotkin, A.V., Roychoudhury, S., Capcarova, M. 2010: Puberty related changes in hormonal levels, productive performance, carcass traits, and their interactions in Slovakian White gilts. Asian-Australasian Journal of Animal Science 23, 182-187. http://dx.doi.org/10.5713/ajas.2010.90279

Kolesarova, A., Slivkova, J., Sirotkin, A., Massanyi, P., Capcarova, M. (2009b) The release of insulin-like growth factor - I by ovarian granulosa cells of pregnant sows after lead and mercury administration in vitro. Slovak Journal of Animal Science 42, 35-41.

Kolodziejczyk, J., Gertler, A., Leibovich, H., Rzasa, J., Gregoraszczuk, E.L. (2003). Synergistic action of growth hormone and insulin-like growth factor I (IGF-I) on proliferation and estradiol secretion in porcine granulosa and theca cells cultured alone or in coculture. Theriogenology 60, 559-570.

Langendijk, P., van den Brand, H., Gerritsen, R., Quesnel, H., Soede, N., Kemp, B. (2008). Porcine luteal function in relation to IGF-1 levels following ovulation during lactation or after weaning. Reproduction in Domestic Animals 43,131-136. Lee, C.Y., Lee, H.P., Jeong, J.H., Baik, K.H., Jin, S.K., Lee, J.H., Sohnt, S.H (2002). Effects of restricted feeding, low-energy diet, and implantation of trenbolone acetate plus estradiol on growth, carcass traits, and circulating concentrations of insulin-like growth factor (IGF)-I and IGF-binding protein-3 in finishing barrows. Journal of Animal Science 80, 84-93.

Liu, X.J., Malkowski, M., Guo, Y., Erickson, G.F., Shimasaki, S., Ling, N. (1993). Development of specific antibodies to rat insulin-like growth factorbinding proteins (IGFBP-2 to -6): analysis of IGFBP production by rat granulosa cells. Endocrinology 132, 1176-1183.

Lucy, M.C. (2008). Functional differences in the growth hormone and insulinlike growth factor axis in cattle and pigs: implications for post-partum nutrition and reproduction. Reproduction in Domestic Animals 43, 31-39. http://dx.doi.org/10.1111/j.1439-0531.2008.01140.x

Mahajan, D.K., 2008: Pig model to study dynamics of steroids during ovarian follicular growth and maturation. In Sourcebook of Models for Biomedical Research, pp 425-436.

Mao, J., Smith, M.F., Rucker, E.B., Wu, G.M., McCauley, T.C., Cantley, T.C., Prather, R.S., Didion, B.A., Day, B.N., 2004: Effect of epidermal growth factor and insulin-like growth factor I on porcine preantral follicular growth, antrum formation, and stimulation of granulosal cell proliferation and suppression of apoptosis in vitro. Journal of Animal Science 82, 1967-1975.

Mondschein, J.S., Etherton, T.D., Hammond, J.M. (1991). Characterization of insulin-like growth factor-binding proteins of porcine ovarian follicular fluid. Biology of Reproduction 44, 315-320.

Onagbesan, O., Bruggeman, V., Decuypere, E. (2009). Intra-ovarian growth factors regulating ovarian function in avian species: a review. Animal Reproduction Science 111, 121-140.

Palma, A,, Arganaraz, M.E., Barrera, A.D., Rodler, D., Mutto, A.A., Sinowatz, F. (2012). Biology and biotechnology of follicle development. Scientific World Journal Article ID 938138, 14 pages. http://dx.doi.org/10.1100/2012/93813

Prunier, A., Louveau, I. (1997). Influence of ovariectomy on metabolic and endocrine parameters during sexual development in the female pig. Journal of Endocrinology 154, 423-429.

Ryan, R.J., 1981: Follicular atresia: some speculations of biochemical markers and mechanisms. Dynamics of Ovarian Function, pp 1-12. New York: Raven Press 
Sandhu, M.S., Dunger, D.B., Giovannucci, E.L. (2002). Insulin, insulin-like growth factor-I (IGF-I), IGF binding proteins, their biologic interactions, and colorectal cancer. Journal of National Cancer Institute 94, 972-980. http://dx.doi.org/10.1093/jnci/94.13.972

Shah, D., Nagarajan, N. (2013). Luteal insufficiency in first trimester. Indian $\begin{array}{lllll}\text { Journal of Endocrinological Metabolism } & 17, & 44-49\end{array}$ http://dx.doi.org/10.4103/2230-8210.107834

Sirotkin, A.V. (2013). New endocrine and intracellular regulators of ovarian functions. Endocrine Abstracts 32, P583, DOI:10.1530/endoabs.32.P583

Sirotkin, A.V., Grossmann, R. (2006). The role of protein kinase A and cyclindependent (CDC2) kinase in the control of basal and IGF-II-induced proliferation and secretory activity of chicken ovarian cells. Animal Reproduction Science 92 , 169-181. http://dx.doi.org/10.1016/j.anireprosci.2005.05.018

Sirotkin, A.V., Makarevich, A.V., Corkins, M.R., Kotwica, J., Bulla, J. (2001) The transfection-induced overexpression of IGF-binding protein-4 affects the secretory activity of porcine ovarian granulosa cells and their response to hormones and IGF-I. Journal of Molecular Endocrinology 26, 241-248.

Sirotkin, A.V., Sanislo, P., Schaeffer, H.J., Florkovicová, I., Kotwica, J., Bulla, J., Hetényi, L. (2004). Thrombopoietin regulates proliferation, apoptosis, secretory activity and intracellular messengers in porcine ovarian follicular cells: involvement of protein kinase A. Journal of Endocrinology 183, 595-604.

Ui, M., Shimonaka, M., Shimasaki, S., Ling, N. (1989). An insulin-like growth factor-binding protein in ovarian follicular fluid blocks follicle-stimulating hormone-stimulated steroid production by ovarian granulosa cells. Endocrinology $125,912-916$

Xi, G., Hathaway, M.R., White, M.E., Dayton, W.R. (2007). Localization of insulin-like growth factor (IGFBP)-3 in cultured porcine embryonic myogenic cells before and after TGF-beta1 treatment. Domestic Animal Endocrinology 33, 422-429.

Yi, Z., Hathaway, M.R., Dayton, W.R., White, M.E. (2001). Effects of growth factors on insulin-like growth factor binding protein (IGFBP) secretion by primary porcine satellite cell cultures. Journal of Animal Science 79, 2820-2826. Zhou, J., Adesanya, O.O., Vatzias, G., Hammond, J.M., Bondy, C.A. (1996) Selective expression of insulin-like growth factor system components during porcine ovary follicular selection. Endocrinology_137, 4893-4901. 